\title{
Salvaging the EU: Two-Speed or Dual-Track Reform?
}

\author{
Steven Rosefielde ${ }^{1}$
}

ABSTRACT

In the most recent decade, the European Union has shown itself to be less robust than globalists imagined. Globalists believed that supranationality was weatherproof - that it would always outperform national alternatives and would survive adversity. Economic stagnation and Brexit belied these expectations. This essay investigates one aspect of the EU's supranational plight: incompatible goals and the difficulty of mutual accommodation, especially during hard times. EU supranationalists contend that the shared dreams assure harmonious results, but experience reveals that supranational government is shakier than advocates claim because shared ideals and benefits have not been enough for members to put aside conflicting national interests. These rivalries do not doom the European Union's globalizing project, but they do expose the vulnerabilities of its premises. Supranational union is proving to be unsatisfactory to both many centralizers demanding "more Europe" and decentralizers insisting on "less Europe". EU leaders are aware of the problem but are wedded to a one-track, two-speed supranational approach that is destined to fail. A dual-track supranational solution analogous to China's "one country, two systems" offers a better alternative.

KEY WORDS: $\quad$ European Union, Reform, Dual-Track

JEL Classification: E02, E52, E61, F36, H63, H77, O52, P11, P17

${ }^{1}$ University of North Carolina at Chapel Hill, Department of Economics, United States

\section{Introduction}

The EU is currently susceptible to sporadic defections because its members no longer share a common view of transnational government and policy and are unwilling to accept the status quo. Powerful members insist upon bending recalcitrant members to their will (coercive adaptation), and participants hold contradictory attitudes toward the obligations implied by solidarity. The precise impact of the EU's internecine struggles on Europe's wellbeing going forward is difficult to calibrate, but the broad prognosis is not promising.

Correspondence concerning this article should be addressed to: Steven Rosefielde, University of North Carolina at Chapel Hill, Department of Economics, Chapel Hill, North Carolina 27514, United States. E-mail: stevenr@unc.edu

\section{American "Supranational" Confederation}

The EU's contemporary dilemma is a replay of the struggle between the American Federalist and AntiFederalist parties in the late $18^{\text {th }}$ century that revolved around three issues. First, America's founding fathers quarreled about the division of powers between Washington and the colonies (later states). Second, they sparred over who should be the people's primary protector, Washington or the states. Third, they fretted about whether the will of the people should control the actions of elected officials and unelected administrators or whether it was sufficient for representatives to govern by consent. The colonies voluntarily participated in the project because each player believed that there existed at least one mutually acceptable positive 
sum solution. The Declaration of Independence, the Constitution and the first ten amendments to the Constitution established the governing rules. The Declaration of Independence, written by the Continental Congress in 1776, envisioned a positive sum confederation of the willing, with implicit rights of nullification and secession from oppressive government. It was an AntiFederalist ("less America") manifesto.

The Constitution embodied Federalist sentiment ("more America"). It broadly subordinated states to Washington's rule but granted them primary authority over public programs, taxation, money and banking. This meant that American federalism until the $20^{\text {th }}$ century was similar to the ("less Europe") European Economic Community (EEC) as established by Belgium, France, Italy, Luxembourg, the Netherlands and West Germany on January 1, 1958 under the Treaty of Rome. The primary difference between the American federalism and the EEC's version of weak transnationality was sovereign control over defense and foreign policy. These powers were Washington's but were retained in the capitals of Europe.

Anti-Federalists initially rejected the Constitution but acquiesced when the Federalists agreed to the adoption of the first ten amendments specifying limits on central authority over individual rights to life, liberty, property, free speech, free press and religion. Like the United Kingdom and Denmark more than two centuries later, Anti-Federalists chose to work for their preferred arrangements within the new constitutional framework. They assumed that states could nullify federal statutes and secede under extreme duress.

"Less America" advocates ultimately lost. Despite the Anti-Federalists' best efforts, including the South's secession on June 8,1861 , the power of America's federal government grew enormously. The unionist civil war victory effectively ended states' rights of nullification and secession. The concentration of central authority intensified after the adoption of the Sixteenth Amendment (Amendment XVI) to the United States Constitution legalizing federal income taxation February 3, 1913 and the founding of the Federal Reserve banking on December 23, 1913 under President Woodrow Wilson. Federal public spending expanded during President Franklin Roosevelt's New Deal (including the Social Security Act of 1935) and President Harry Truman's Employment Act of 1946, which cre- ated the Council of Economic Advisers. Since the early 20th century, both federal and state courts have used the Fourteenth Amendment (citizenship rights, equal protection) to apply portions of the Bill of Rights to state and local governments. This was supposed to strengthen individual rights to life, liberty, property, and free speech and the rule of law but in the new millennium has weakened them.

The European Union emulated the American precedent in most of these regards under the Maastricht Treaty (1992-2007) establishing the Euro as the common currency for most members, and the Lisbon Treaty (2007-present) merging the EU three pillars system into a single legal entity with a Single Market. The key exceptions are "fiscal union", military and foreign policy. EU member states have more national autonomy in these regards than America's states, including the de facto right of secession (Brexit). EU economic and social regulatory policy, however, in many respects is more comprehensive and unified than America's, and the EU suffers from a "democratic deficit" (regulatory policy set in Brussels by the European Commission, a bureaucracy that is unaccountable to the people). (Gretschmann, 2016).

\section{American "Tossed Salad versus "Melting Pot"}

Social context is another aspect of the American experiment that merits attention in binary comparisons between US federalism and EU supranationality. American society from the outset was a "tossed salad" rather than a melting pot. Bachmann (2016). The "new world" was colonized by a multitude of European ethnic and religious groups. The population was predominantly white and socially stratified, but there were significant African American and native Indian communities. The economies of the Northern and Southern states were distinct. The North featured small family farming, industry and commerce, the South slave-intensive plantations.

Federalists found this diversity distasteful. They preferred a common national culture befitting a great nation and sought to achieve it by making the "melting pot" the centerpiece of the "American project" up to and after the civil war. Although contemporary America's establishment celebrates diversity, it hopes to forge an assimilated society with superior progressive characteristics in the not-too-distant future. 


\section{EU “Tossed Salad versus "Melting Pot”}

The evolution of EU society parallels the American experience. The EEC from the outset was a "tossed salad" rather than melting pot and became even more so with the accession of new members. Its population is ethnically, religiously and increasingly racially diverse. Society is stratified, ruled by elite establishments opposed to direct democracy. There are North/South and East/West productivity divides.

"More Europe" EU leaders, such as the Federalists, prefer an assimilated society with superior progressive characteristics and have made the "melting pot" the centerpiece of the "European project". Although lip service is paid to diversity, the entire population including non-European immigrants is supposed to converge to the approved archetype. This conformity is a non-negotiable part of the transnational bargain for "more EU" advocates.

\section{Terms of Engagement}

Government is primarily about power, not efficiency. The EU presents itself as a positive sum game for the European people by stressing the static, dynamic and synergistic economic benefits of the Common Market and Single Market (including wellbeing), Thaler (2015). but its leaders pay even closer attention to personal power and parochial gains. "More Europe" advocates try to impress "less Europe" partisans that positive sum economic and social benefits in the EU "melting pot" justify "staying", while "less Europe" advocates such as the UK contend that they are being forced to play a negative sum game, that their only rational choice is exit. Neither position is true nor false because deeply felt judgments at all levels are normative. They are also mutable. The UK's attitude toward exit today would likely be very different if the Maastricht economic miracle had endured and the 2015 refugee immigration shock better managed. These seminal events drastically changed perceptions of future net benefits for various important players, requiring renegotiation of the terms of supranational union.

\section{Europe at Loggerheads}

EU leaders know that they should renegotiate the terms of engagement to reduce member conflict and deter defections, (European Commission, 2017). but "more Europe" partisans (primary beneficiaries of the positive sum game) are not yet prepared to horse trade. They are convinced that they can tweak central economic institutions to cure all ills, turbocharging their quest for zero sum benefits at the expense of "less Europe" advocates. (Rosefielde \& Dallago, 2019). The only concession advanced by "more Europe" partisans currently on the table is "two-speed" (quick and slow) federalist convergence. (European Union, 2017; European Commission, 2017). The approach may be a sound bargaining ploy but is tone deaf to the new European environment. "More Europe" is sure to exacerbate bruised feelings unless there is a second Maastricht economic miracle (Grabbe \& Stefan, 2017).

\section{Formation and evolution of the European Union}

Nation states before World War II never voluntarily surrendered control over their fiscal, monetary, financial, legal, defense, education, social or foreign policy as part of a package to achieve common goals, even though they participated in international institutions such as the League of Nations. The horrors of WWII, combined with cold war politics and the welfare state tide, however, propelled Europe along a novel supranational trajectory with some unintended consequences. On September 19, 1946, Winston Churchill gave a speech in Zurich advocating not only Franco-German rapprochement but also a kind of United States of Europe called a European "Third Way." Churchill can be considered the EU's founder. He also advocated a "Council of Europe" formed thereafter with the assistance of French Foreign Minister Robert Schuman, mandated to create supranational communities on the path to a fully democratic, integrated Union. The Schuman Declaration May 9, 1950 reaffirmed the concept in conjunction with the formation of the European Coal and Steel Community (ESCS). It proclaimed the European Community as the world's first supranational institution, marking the "birth of modern Europe" and initiating an epoch where intra-European wars were said to be impossible.

Schuman's utopian vision, which can be traced back to France's first socialist Claude Henri de Rouvroy, comte de Saint-Simon (1760-1825) [On the Reorganization of European Industry, 1814] was the prelude to a succession of transitionary developments culminating in today's European Union. 
Membership in Churchill's and Schuman's club was open to any European nation willing to participate in a supranational community on the path to discovering whether the group could devise a satisfactory "onetrack" fully democratic federal entity. Belgium, France, Germany, Italy, Luxembourg and the Netherlands, signatories to the 1958 Treaty of Rome, are the EU's founding fathers and remain core supporters of "more Europe".

Great Britain, Ireland and Denmark joined the founders in 1973. The British and Danish publics were Euroskeptics from the outset. Their leaders were attracted to the economic benefits of tariff elimination in a common market but were more ambivalent about deeper economic and political integration including subsequent monetary union and proposals for supranational regulation of fiscal, political, social, juridical, police, foreign affairs and defense matters. Britain and Denmark refused to join the Eurozone.

Greece and Spain became EU members in the 1980s, both aware of efforts to construct a European monetary union, open borders (Schengen agreement) and create a Single Market. They and the fifteen other countries that signed on after the Soviet Union's demise primarily sought economic benefits but also agreed to explore the evolving one-track federative possibilities urged by the founding six. The details of the ideal one-track federation with supranational characteristics remain as elusive today as they were at the outset of the project. What will be the characteristics of an all-union "one-track" trans-nationalized culture, and who will rule at the end of the day? Will the regime be hegemonic, or will democracy prevail?

\section{Fiscal union}

Proponents of "more Europe" understandably are loath to offer specifics about the distribution of real authority and the details of the homogenized culture but nonetheless have pressed this abstract agenda under the banner of fiscal union. The slogan "more Europe" for the moment means perfecting the Single Market, establishing a lender of last recourse for the Eurozone, and complementing monetary union with a unified transnational fiscal system that will supplant aspects of national taxing authority and strengthen supranational public policymaking. Most macroeconomic theorists believe that a federation will empower sound macroeconomic management and restore pros- perity (Grauwe, 2010; Razin \& Rosefielde, 2016; Rosefielde \& Razin, 2012a; 2012b; Rosefielde, 2015; Sargent, 2012). It promises a generally competitive, optimally macromanaged economically integrated system with "inclusive" sensibilities (Rosefielde, 2018; Rosefielde \& Dallago, 2019; Tirole, 2015).

\section{Euroskepticism}

Euroskeptics do not deny the virtues of economic efficiency, stability, integrated macroeconomic management, coordinated supranational public policy and social solidarity. They acknowledge the microeconomic benefits of widened markets, free trade and finance but contend that Eurocrats cannot deliver what they promise and have hidden agendas (Fleming, 1962; McKinnon, 1963; Mundell, 1963). They believe that full costs will exceed the gains including external economies. Specifically, they assert that Brussels and Berlin abuse their decision-making powers in their own interests and seek to undemocratically expand their bureaucratic control not only over the EU economy but comprehensively over all dimensions of members' political, social, cultural, foreign, and defense activities (Bolton, 2016). They recognize that Brussels and Berlin portray themselves as skillful benevolent technocrats but contend that "more Europe" insiders act primarily on their own behalf at others' expense. (Gretschmann, 2016).

Euroskeptics also contend that "less Europe" members who had played for time are discovering that this is a losing game. The "more Europe" camp in accordance with America's historical experience is successfully imposing its will on the EU forcing dissenters to accept the new normal or leave. Euroskeptics insist that there are no longer any prospects for "less Europe" to accommodate club members who prefer a weaker form of association in a "one-track" framework. Supranationalism in their eyes has become a hollow concept. The superstate as they see it is engulfing and devouring independent member nations.

The EU as it is presently constituted is a failing economic project for them, compounded by democratic disempowerment (Dallago \& McGowan, 2016; Dallago, Guri, \& McGowan, 2016). The Greeks are particularly adamant about the economic burden of one-track EU membership. The British, in contrast, place the emphasis the other way around. They do not want Brussels and Berlin to govern them and are less 

unemployment rose above $50 \%$, despite a sharp austerity-impelled internal devaluation.

The hardship inflicted by this rollercoaster ride prompted a democratic revolt. On July 5, 2015, 62\% of Greeks voted to reject an EU-, ECB-, and IMF-backed debt relief package, effectively opting for Grexit. If the Greek people had had their druthers, their leaders would have exited the EU. Prime Minister Alexis Tsipris, however, decided otherwise. He chose instead to sign a deal worth 86 billion euros over three years laden with conditions, such as tax hikes and pension reforms, considered by critics to be so tough that social media buzzed with talk of a coup d'etat.

Tsipras's capitulation in the face of a popular mandate can be variously interpreted. Some construe it to mean that the Prime Minister grasped the indispensability of Eurozone membership regardless of the intermediate costs. Some portrayed it as a "sellout" that sacrificed the public good for the benefit of powerful insiders, while others attributed his action to the risk of devastating punitive actions by the ECB. The latter interpretation is the most interesting from the standpoint of appraising the EU's future. It points to the possibility that the EU's merit depends not only on rational free choice but also on the risks of superstate economic and political coercion.

\section{Supranational capital flight}

Greece may have capitulated to Germany to avert capital flight of a novel sort that took most observers by surprise. Greeks began withdrawing unsustainable amounts of euro deposits from private banks because they correctly feared that the ECB might cut off currency supplies in an attempt to jawbone Tsipras into accepting structural reform. Capital flight traditionally has been associated with hot money fleeing currencies ripe for devaluation. The Greek case was different. Euro devaluation was not an issue. Depositors fled Greek banks because they wanted to retain access to the euro, not because they feared euro devaluation. They recognized that the ECB might curtail euro access and that Greek banks might collapse if a run-forthe-liquid-euro could not be accommodated due to a shortage of liquid bank assets.

The phenomenon can be dubbed "supranational capital flight" because it is a logical consequence of the EU governance scheme that allows national banks to operate with a currency national authorities do not control. Rational actors foreseeing a looming confrontation between supranational and national authorities will always find it costless to take their money and run, holding euros in cash and redepositing them in Helsinki or purchasing other currencies.

This vulnerability and the difficulty of quickly readopting the drachma was invisible as long as cooperation and consensus were mandatory. Shutting off the ECB spigot (Target 2) was unimaginable. Now that the genie is out of the bottle, however, it can be plausibly assumed that coercive methods, including Eurozone supranational capital flight, could be invoked whenever debt to GDP ratios expand, and the danger of confrontation within EU governance structures looms.

\section{Brexit}

Britain's decision to cancel its membership in club EU is obliquely connected to Grexit. Voters were aware of Greece's plight, but Britain was not a Eurozone member. Supranational capital flight therefore was irrelevant. Nor was Britain overindebted by the standards of other EU members. (CIA, 2019). Its post-financial crisis growth and employment were the best in the EU. Some argued that Britain's macro performance would have been more vibrant if it were not entangled with the EU; however, the principal grievance motivating referendum voters was forced public goods substitution, including control over migrants and refugees. Euroskeptics felt that Eurocrats restricted local public policy choice, generated strong downward wage pressure, exacerbated involuntary unemployment, intensified unwelcome foreign labor migration (Dallago \& McGowan, 2016), increased terrorist risk, and drew them too deeply into Germany's political orbit (Mills \& Rosefielde, 2016). They argued moreover that Eurocrats were unelected and unresponsive to the British people's will.

It can be counterargued that British voters were ill informed about these issues in varying degrees, but truth is peripheral to the larger question of EU survivability. Advocates of "more Europe" displayed an inability to defuse grievances essential for the survival of the Greater Europe project.

\section{Dual-Track Option}

Brussels and Berlin are unlikely to accommodate demands for "less Europe" anytime soon. Their convic- 

Dallago, B. (2016). The Progressive Rift of the Eurozone: Risks and Remedies. The Singapore Economic Review, 63(4), 943-965.

Dallago, B., \& McGowan, J. (2016). Crises in Europe in the Transatlantic Context: Economic and Political Appraisals. London, UK: Routledge.

Dallago, B., Guri, G., \& McGowan, J. (Eds.). (2016). A Global Perspective on the European Economic Crisis. London, UK: Routledge.

European Commission. (2017). Reflection Paper on the Deepening of the Economic and. Brussels. Available at https://ec.europa.eu/commission/sites/betapolitical/files/reflection-paperemu_

European Union. (2017). The Rome Declaration, Declaration of the leaders of 27 member states and of the European Council, the European Parliament and the European Commission. Brussels: European Council. Available at https://www.consilium. europa.eu/en/press/press-releases/2017/03/25/ rome-declaration/

Fleming, M. (1962). Domestic Financial Policies under Fixed and Flexible Exchange Rates. Washington, DC: International Monetary Fund.

Giles, C. (2016, June 27). Brexit in Seven Charts - the Economic Impact. Financial Times. Available at https://www.ft.com/content/0260242c-370b11e6-9a05-82a9b15a8ee7

Grabbe, H., \& Stefan, L. (2017). Defending EU Values in Poland and Hungary, Carnegie Europe. Available at http://carnegieeurope.eu/2017/09/04/defending-eu-values-in-poland-and-hungarypub-72988

Grauwe, P. D. (2010). The Greek Crisis and the Future of the Eurozone. The Structural Problem in the Eurozone is Created by the Fact that the Monetary Union is not Embedded in a Political Union. Brussels: Euro Intelligence.

Gretschmann, K. (2016). The EU in Stormy Seas: Beginning of the End or End of the

Beginning. In. B. B. Dallago, G. Guri, \& J. McGowan (Eds.), A Global Perspective on the European Economic Crisis (pp. 21-32). London, UK: Routledge.

Jarman, H., \& Greer, S. (2016). Reinforcing Europe's Failed Fiscal Regulatory State. In B. Dallago, G. Guri, \& J. McGowan, A Global Perspective on the European Economic Crisis. London, UK: Routledge.
Maddison, A. (2003). The World Economy: Histoical Statistics. Alailable at http://www.ggdc.net/maddison/Historical_Statistics/horizontal-file_032009xls

McKinnon, R. (1963). A Theory of Optimum Currency Areas. American Economic Review, 51(4), 657-665.

Mills, Q., \& Rosefielde, S. (2016). The Trump Phenomenon and Future US Foreign Policy. Singapore: World Scientific Publishers.

Mundell, R. (1963). Capital Mobility and Stabilization Policy under Fixed and Flexible Exchange Rates. Canadian Journal of Economic and Political Science, 25(4), 475-485.

Piattoni, S. (2016). Institutional Innovations and EU Legitimacy after the Crisis. In J. McGowan, \& B. Dallago, Crises in Europe in the Transatlantic Context: Economic and Political Appraisals. London, UK: Routledge.

Piketty, T. (2014). Capital in the Twenty-First Century. Cambridge, UK: Harvard University Press.

Razin, A., \& Rosefielde, S. (2016). Israel and Global Developments 1990-2015: Riding with the Global Flows and Weathering the Storms (Working Paper No. 22567). The National Bureau of Economics Research. Retrieved from https://www.nber.org/ papers/w22567.pdf

Razin, A., \& Rosefielde, S. (forthcoming). The European Project after Greece's Near Default. Israel Economics Journal.

Rosefielde, S., \& Razin, A. (2012a). A Tale of a Politically-Failing Single-Currency Area. Israel Economic Review, 10(1), 125-138.

Rosefielde, S., \& Razin, A. (2012b). What Really Ails the Eurozone? Fualty Supranational Architecture. Contemporary Economics, 6(4), 10-18.

Rosefielde, S. (2015). The Mundell-Fleming Trilemma and EU De-Legitimation. In B. Dallago, \& J. McGowan, Crises in Europe in the Transatlantic Context: Economic and Political Appraisals. London, UK: Routledge.

Rosefielde, S., \& Pfouts, R. (2015). Inclusive Economic Theory. Singapore: World Scientific Publishers.

Rosefielde, S. (2016a). The European Project: Moving Forward with Dry Eyes. In G. Gury, \& J. McGowan, A Global Perspective on the European Economic Crisis. London, UK: Routledge. 
Rosefielde, S. (2016b). Grexit and Brexit: Rational choice, compatibility, and coercive adaptation. Acta Oeconomica, 66, 77-91.

Rosefielde, S., \& Liu, Y. (2017). Sovereign Debt Crises: Solidarity and Power. The Journal of Comparative Economic Studies, 12, 101-112.

Rosefielde, S. (2018). Salvaging the European Union: The Inclusive Multi-Track Supranational Option. HOLISTICA - Journal of Business and Public Administration, 8(3), 7-18.

Rosefielde, S., \& Dallago, B. (2019). The strange fate of Brexit and Grexit and the Eurozone. Contemporary Economics, 13(1), 99-106.

Sargent, T. (2012). Nobel Lecture: United States Then, Europe Now. Journal of Political Economy, 120(1), $1-40$.

Thaler, T. (2015). Misbehaving: The Making of Behavioral Economics. New York, NY: W. W. Norton \& Company.

Tirole, J. (2015). Country Solidarity in Sovereign Crisis. American Economic Review, 105(8), 2333-2363. 
